\title{
The effect of zinc status on the immune function of diabetic rats
}

\author{
A. D. Mooradian ${ }^{1,3}$ D.C. Norman ${ }^{2,3}$ and J. E. Morley ${ }^{1,3}$ \\ ${ }^{1}$ GRECC Sepulveda V.A. Medical Center and ${ }^{2}$ Wadsworth V.A. Medical Center and \\ ${ }^{3}$ Department of Medicine, UCLA School of Medicine, Los Angeles, California, USA
}

\begin{abstract}
Summary. To evaluate the role of zinc status in immune system dysfunction in diabetic animals, the interleukin-2 production and the lymphocyte mitogenic response to phytohaemagglutinin, concanavalin A and lipopolysaccharide were measured in streptozotocin-induced diabetic rats, diabetic rats treated with insulin and their non-diabetic controls maintained on low zinc, normal zinc and high zinc diets for 3 weeks. Unstimulated lymphocyte proliferation was significantly lower in diabetic rats compared to nondiabetic control rats maintained on normal zinc diet $(1505 \pm 318 \mathrm{vs}$ $3447 \pm 497 \mathrm{cpm})(p<0.005)$ or low zinc diet $(546 \pm 191 \mathrm{vs}$ $4011 \pm 628 \mathrm{cpm})(p<0.005)$. High zinc diet attenuated the difference between the diabetic rats $(2404 \pm 833 \mathrm{cpm})$ and control rats $(3929 \pm 713 \mathrm{cpm})$. Insulinised diabetic rats were similar to control rats. Phytohaemagglutinin-stimulated lymphocyte proliferation was not significantly altered with dietary zinc changes, but diabetic rats on low zinc diet had significantly lower $(p<0.025)$ values compared to control rats on the same diet $(41470 \pm 7874$ vs $72308 \pm 8895 \mathrm{cpm})$. In -
\end{abstract}

sulinisation did not normalise phytohemaegglutinin-stimulated lymphocyte proliferation $(40711 \pm 3666 \mathrm{cpm})$. Similarly, cells from diabetic rats on low zinc diet, unlike their controls, failed to respond to concanavalin A stimulation. Compared to control rats the diabetic rats on either low or normal zinc diets had lower lipopolysaccharide-stimulated lymphocyte proliferation. High zinc diet or insulinisation normalised mitogenic response of lymphocytes to lipopolysaccharide. Unlike the diabetic rats alterations in dietary zinc intake did not significantly affect the lymphocyte proliferation in control rats. Neither the diabetic state nor zinc status had any significant effect on interleukin-2 production. Thus, zinc status of the animal is an important determinant of cell-mediated immunity, but additional factors peculiar to the diabetic state may be involved in the modulation of the immune system in diabetes.

Key words: Diabetes, zinc, immune system, lymphocyte mitogenesis.
Some of the major causes of morbidity and mortality in diabetic patients are related to impaired immune function [1-6]. The cause of the immune system dysfunction in diabetes mellitus is multifactorial and may be related in part to zinc status. Zinc has an important role in modulating the immune system [7-9] and diabetic patients are at risk of developing zinc deficiency [10]. Zinc supplementation in elderly subjects over 70 years of age resulted in a significant improvement in the number of circulating T-cells, delayed cutaneous hypersensitivity, and the antibody response to tetanus vaccine [11]. Similarly, Steidemann and Harrell [12] found a correlation between serum zinc and post-immunisation antibody titres to influenza vaccination in elderly women. Zinc deficiency is associated with low peripheral blood natural killer cell activity [13] and decreased lymphocyte responses to phytohaemagglutinin (PHA) and other mitogens [8, 9]. Zinc supplementation improved the natural killer cell activity in zinc deficient mice [14]. Salutary effects of zinc supplementation on PHA response is found in patients with lung cancer and low serum zinc levels [15] as well as in diabetic patients [16]. However, the natural killer cell activity in these patients did not improve with zinc replacement $[15,16]$. Studies in animal models of diabetes have also indicated a significant alteration in the immune status [17-22]. It is not known whether zinc supplementation would partially or completely normalise the lymphocyte response to mitogens in these animals. Donaldson et al. [18] concluded that zinc deficiency does not contribute substantially to the impaired in vivo cell mediated-immunity in the genetically diabetic mouse. 
Circumstantial evidence in the literature suggests an important role of zinc status in immune system dysfunction of diabetes. A causal role of zinc deficiency in the impaired immune response in diabetes would be suggested if zinc deficiency in non-diabetic control animals results in alteration in immune function similar to those in diabetic animals, and if zinc supplementation reverses these alterations in diabetic animals. Furthermore, a zinc-deficient diet should aggravate impairment of the immune system in diabetic animals.

\section{Materials and methods}

\section{Materials}

${ }^{3} \mathrm{H}$-Thymidine (specific activity $6.7 \mathrm{Ci} / \mathrm{mmol} / \mathrm{l}$ ) was obtained from New England Nuclear (Boston, Mass, USA). Biochemicals were obtained from Sigma Chemical Co. (St. Louis, Mo, USA). The test diets were purchased from Teklad diets (Madison, Wis, USA).

\section{Animals}

Male (CDF) (F-344) rats of 3 months of age were obtained from Harlan Industries (Indianapolis, Ind, USA). 1.3\% solution of streptozotocin (Upjohn Co., Kalamazoo, Mich, USA) in $0.05 \mathrm{~mol} / 1 \mathrm{cold}$ citrate buffer ( $\mathrm{pH} 4.5$ ) was injected i. p. at a dose of $45 \mathrm{mg} / \mathrm{kg}$ body weight. The control rats were concurrently injected with citrate buffer. The animals were maintained on regular rat chow and water ad libitum. Those rats manifesting glucosuria, polydipsia, polyphagia and weight loss were considered diabetic. The urinary excretion of ketones measured by Keto-Diastix (Ames Miles Laboratories, Elkhart, Ind, USA) was either trace or negative. In addition, a group of streptozotocin - diabetic animals was given neutral protamine of Hagedorn (NPH) insulin, $10 \mathrm{u} / \mathrm{kg}$ s.c. twice daily. The plasma glucose was measured on the day of killing. Three weeks after streptozotocin treatment, diabetic rats and their controls were subdivided into three diet groups. Each rat was housed individually and its body weight, food and water intake were monitored. The first group of rats was fed a zinc deficient diet containing $0.5 \mu \mathrm{g} \mathrm{Zn} / \mathrm{g}$, the second group was fed a normal diet containing $37.5 \mu \mathrm{g} \mathrm{Zn} / \mathrm{g}$, and the third group of rats was fed a zinc supplemented diet containing $1.0 \mathrm{mg} \mathrm{Zn} / \mathrm{g}$. All the rats were given double distilled water ad libitum containing less than $1.0 \mu \mathrm{g} \mathrm{Zn} / 1$. Necessary precautions were taken to minimize coprophagia. The rats were pair-fed with the group on zinc deficient diet. On the average, the diabetic rats were given $15 \mathrm{~g}$ chow/day per rat and the control rats were given $10 \mathrm{~g}$ chow/day per rat. The animals were kept on these diets for three weeks after which, under pentobarbital anaesthesia $(50 \mathrm{mg} / \mathrm{kg}$ i.p.), they were killed by exsanguination from the abdominal aorta. The internal organs and samples of hair were collected for mineral metabolism studies; the preliminary results are published elsewhere [23]. In a subset of rats in each group $(n=5)$, a portion of spleen was collected for measurement of zinc content.

\section{Spleen cell mitogenic response}

The spleen was excised and kept in tissue culture media on ice until use. The tissue culture media used in these experiments was RPMI 1640 containing $25 \mathrm{~mol} / 1$ HEPES buffer supplemented with $10 \%$ heat - inactivated fetal calf serum (GIBCO, Grand Island, NY, USA), $80 \mu \mathrm{g} / \mathrm{ml}$ gentamicin (Schering Corp., Kenilworth, NJ, USA), and $300 \mu \mathrm{g}$ fresh glutamine/ $\mathrm{ml}$ (complete medium with a zinc content of $0.6 \mu \mathrm{g} / \mathrm{ml}$ [24]. The splenic cells obtained by teasing were suspended in RPMI complete medium and washed once. The cell density was adjusted to $1.25 \times 10^{6}$ cells $/ \mathrm{ml} .200 \mu \mathrm{l}$ of cell suspension $2.5 \times 10^{5}$ cells were delivered in triplicate to flat - bottom microtitre plates.

The concentration of the mitogens used was as follows: phytohaemagglutinin (PHA) $1.25 \mu \mathrm{g} / \mathrm{ml}$, concanavalin A (Con A) $2 \mu \mathrm{g} / \mathrm{ml}$ and lipopolysaccharide (LPS) $8 \mu \mathrm{g} / \mathrm{ml}$. The cells were incubated under $5 \% \mathrm{CO}_{2}-95 \% \mathrm{O}_{2}$ for $56 \mathrm{~h}$ at $37^{\circ} \mathrm{C}$. The cells were then pulsed for $16 \mathrm{~h}$ with $0.4 \mu \mathrm{Ci}$ of ${ }^{3} \mathrm{H}$-thymidine in $10 \mu \mathrm{l}$ of media. At the end of incubation the cells were harvested onto glass fibre strips with a cell harvester (model M12-V; Biomedical Research Inst., Rockville, Md, USA). The radioactivity was counted in a Beckman liquid scintillation counter.

\section{Interleukin-2 (IL-2) assay}

The IL-2 assay was carried out as described previously [25]. In brief IL-2 was produced by stimulating the spleen cells $\left(2 \times 10^{6}\right.$ cells $\left./ \mathrm{ml}\right)$ in RPMI 1640 complete medium with Con $A(2 \mu \mathrm{g} / \mathrm{ml})$ and 2 -mercaptoethanol $\left(5 \times 10^{-5} \mathrm{~mol} / 1\right)$ for $24 \mathrm{~h}$. The supernatant was collected, frozen at $-70^{\circ} \mathrm{C}$ until the IL-2 assay was performed. A volume of $100 \mu \mathrm{l}$ from each of 4 two-fold serially diluted IL-2 samples $(1 / 2$ to $1 / 16)$ were delivered to the microwells followed by the addition of $100 \mu$ l of twice washed IL-2 dependent CTLL-2 cells (which had been adjusted to $5 \times 10^{4}$ cells $/ \mathrm{ml}$ ). The cultures were incubated at $37^{\circ} \mathrm{C}$ for $20 \mathrm{~h}$ in a $5 \% \mathrm{CO}_{2}$-humidified incubator. $0.4 \mu \mathrm{Ci}$ of ${ }^{3} \mathrm{H}$ thymidine in $10 \mu \mathrm{l}$ was added to each well and $4 \mathrm{~h}$ later the cells were harvested onto glass fibre strips with a cell harvester (Biomedical Research Inst.), and processed for detection of radioactivity. IL2 activity was expressed in units based on probit analysis described by Gillis et al [26]. The same rat IL-2 standard was used in all IL-2 assays and was arbitrarily assigned an activity of 100 units.

\section{Statistical analysis}

Results are presented as mean \pm SEM. The statistical analysis was done by two way analysis of variance (ANOVA). A $p$ value of $<0.05$ was considered statistically significant.

\section{Results}

Table 1 summarizes the body weights before and after 3 weeks (Day 21) of dietary manipulation and the plasma glucose levels on the day of killing. Splenic zinc content in a subset of animals ( $n=5$ in each group) is also shown. The body weight of diabetic animals at the end of 3 weeks was significantly lower than that of the control rats irrespective of dietary zinc intake $(p<0.001)$. Insulinisation with normalisation of plasma glucose levels prevented weight loss in diabetic rats. The body weight of control rats on zinc deficient diets was modestly lower than the weight of those maintained on normal or high zinc diets. Dietary zinc content did not significantly affect total body weights or plasma glucose levels of diabetic rats. The splenic zinc content was not altered with neither diabetes nor with the alterations in dietary zinc intake.

Table 2 summarizes the results of ${ }^{3} \mathrm{H}$-thymidine incorporation in lymphocytes isolated from control and 
Table 1. The plasma glucose, spleen zinc content and body weight of control (C), diabetic (DM) and insulinised diabetic (DM/Ins) rats maintained on low, normal and high zinc diets

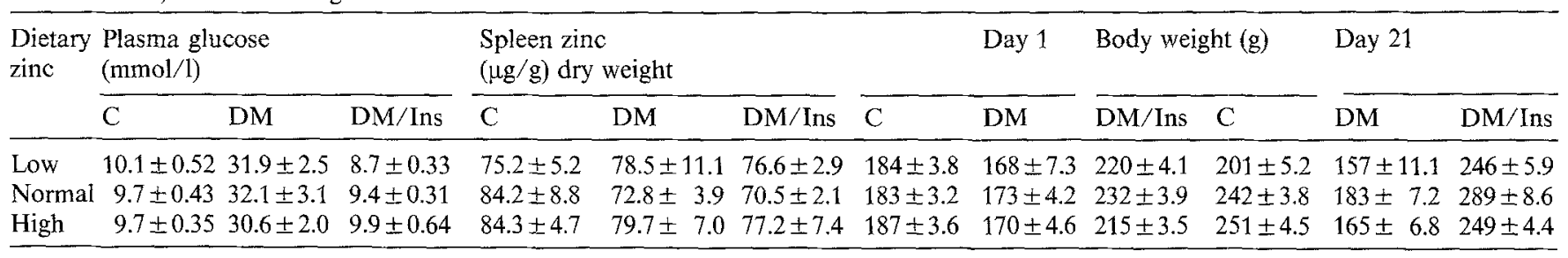

Table 2. ${ }^{3} \mathrm{H}$-thymidine incorporation (cpm) in $2.5 \times 10^{5}$ unstimulated lymphocytes (baseline) and in lymphocytes stimulated with phytohaemagglutinin (PHA); concanavalin A (Con A) and lipopolysaccharide (LPS) ${ }^{a} p<0.025,{ }^{b} p<0.005$ compared to control rats on the same diet; ${ }^{c} p<0.025,{ }_{p}{ }_{p}<0.005$ compared to normal zinc diet within each experimental group. (mean \pm SEM)

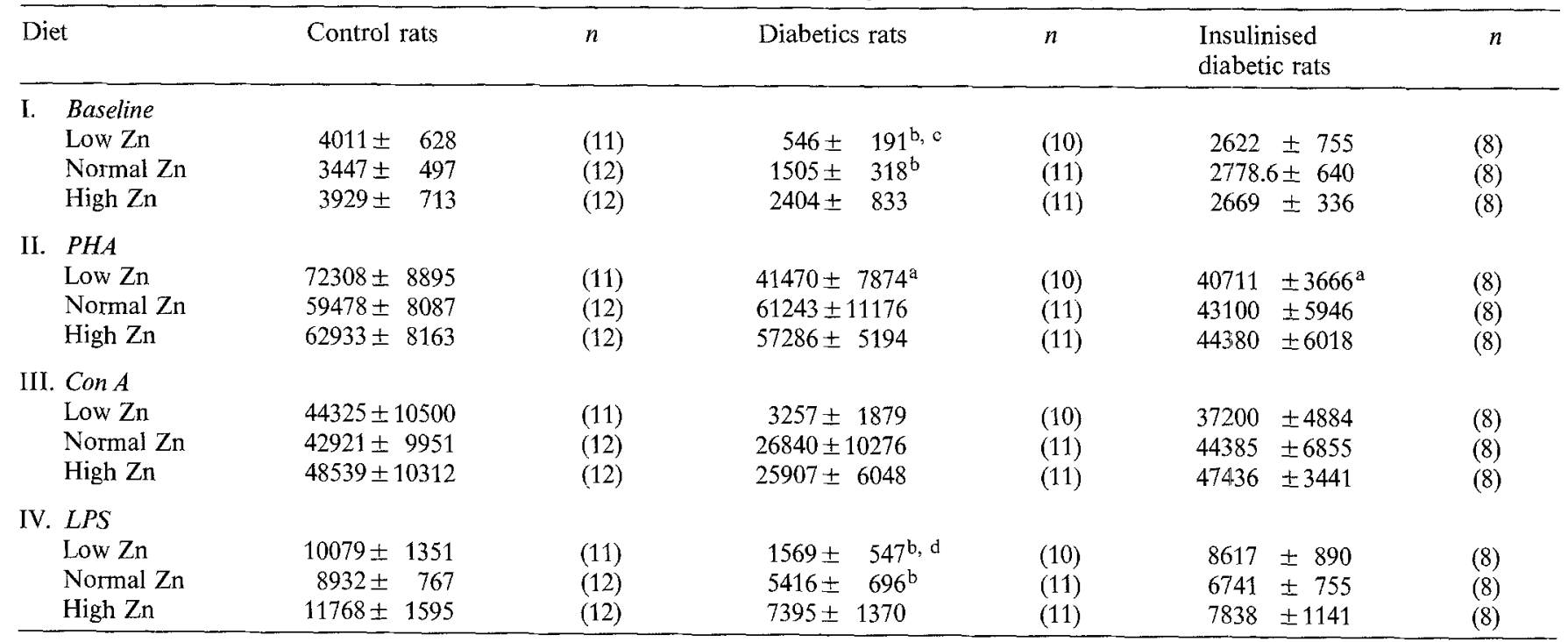

diabetic rats maintained on different diets. Unstimulated lymphocyte proliferation was significantly lower in diabetic compared to control rats maintained on a normal zinc diet $(1505 \pm 318 \mathrm{vs} 3447 \pm 497 \mathrm{cpm}$, $p<0.005)$ or low zinc diet $(546 \pm 191$ vs $4011 \pm$ $628 \mathrm{cpm} p<0.005$ ). High zinc diet attenuated the difference between the diabetic $(2404 \pm 833 \mathrm{cpm})$ and control rats $(3929 \pm 713 \mathrm{cpm})$. Changes in dietary zinc content had no effect on control rats, but high zinc diet compared to low zinc diet had a significant potentiating effect on baseline lymphocyte proliferation in diabetic animals $(p<0.01)$. The unstimulated lymphocyte proliferation of insulinised diabetic rats was similar to that of control rats.

Phytohaemagglutinin (PHA) - stimulated lymphocyte proliferation was not significantly altered with dietary zinc changes either in control rats or in diabetic rats. However diabetic rats on low zinc diet had significantly lower PHA-stimulated lymphocyte proliferation compared to control rats on the same diet $(41470 \pm 7874$ vs $72308 \pm 8895 \mathrm{cpm}, p<0.025)$. Insulinisation did not normalise PHA-stimulated lymphocyte proliferation $(40711 \pm 3666 \mathrm{cpm})$. Similar results were found with concanavalin A (Con A) stimulation. The diabetic rats on low zinc had poor response to Con A (baseline $546 \pm 191 \mathrm{cpm}$, stimulated $3257 \pm$
Table 3. Interleukin- 2 production by $5 \times 10^{6}$ lymphocytes $/ \mathrm{ml}$ following stimulation with concanavalin $\mathrm{A}(2 \mu \mathrm{g} / \mathrm{ml})$ and 2-mercaptoethanol $\left(5 \times 10^{-5} \mathrm{~mol} / \mathrm{l}\right)$ for $24 \mathrm{~h}$. (mean $\left.\pm \mathrm{SEM}\right)$. The differences are not significant

\begin{tabular}{llll}
\hline Diet & Control rats & Diabetic rats & $\begin{array}{l}\text { Insulinised } \\
\text { Diabetic rats } \\
(n=8)\end{array}$ \\
\hline Low $\mathrm{Zn}$ & $313.2 \pm 16.3$ & $320.2 \pm 27.8$ & $346 \pm 22.4$ \\
Normal $\mathrm{Zn}$ & $325.6 \pm 14.6$ & $339.8 \pm 34.2$ & $326.9 \pm 26.8$ \\
High $\mathrm{Zn}$ & $350.4 \pm 24.4$ & $333.8 \pm 44.3$ & $346.3 \pm 13.4$ \\
\hline
\end{tabular}

$1879 \mathrm{cpm})$. Insulinisation normalised Con A stimulated lymphocyte response $(37200 \pm 4884 \mathrm{cpm})$. Dietary zinc alterations in control rats did not affect Con A stimulated lymphocyte proliferation.

The diabetic rats on low or normal zinc diet had lower lipopolysaccharide (LPS) stimulated lymphocyte proliferation compared to control rats on similar diets. Dietary zinc alterations significantly altered LPSstimulated lymphocyte proliferations in diabetic rats but not in control rats. Insulinisation normalised LPS. stimulated lymphocyte proliferation.

Neither the diabetic state nor zinc status had any significant effect on interleukin-2 (IL-2) production by lymphocytes (Table 3). 


\section{Discussion}

Although zinc deficiency and immune system dysfunction are common in diabetes, the role of zinc status in diabetic animals in immune system alterations has been questioned [18]. Thus, impaired in vivo cell-mediated immunity in genetically diabetic $\mathrm{db} / \mathrm{db}$ mice could not be correlated with serum or femur zinc content [18]. Similarly, in non-diabetic littermates, low serum and femur zinc was achieved after 4 weeks of feeding a zinc-deficient diet without evidence of impaired T-cell cytotoxicity [18]. Theoretically, any attempt to correlate a biological function in diabetic animals with serum or tissue content of zinc is complicated by the fact that diabetes associated alterations in tissue zinc content are variable, and intracellular compartmentalisation of zinc rather than total tissue zinc content may be a more important determinant. A role for zinc in diabetes-associated immune system dysfunction would be suggested if (1) a zinc-deficient diet fed to control rats resulted in impairment of immune function (as measured by lymphocyte proliferation and IL-2 production) similar to diabetic animals, and (2) a high zinc diet improved immune function in diabetic animals without affecting the control rats. Three possible caveats in such an approach should be recognised. First, duration of diabetes may not be sufficient to produce the biological changes of interest; second, the duration of feeding a zinc-deficient diet may not be long enough to result in any alterations in the parameters measured; and thirdly, a high zinc diet may have toxic effects. In the present study, diabetes mellitus for a total of 6 weeks resulted in a significant decrease in both basal and LPS-stimulated lymphocyte proliferation. It is unlikely, though possible, that longer duration of diabetes would have altered the other parameters of immune function studied. Feeding a zinc deficient diet for 3 weeks did not affect the measured parameters in the control rats but aggravated the impairment in LPS, Con A and PHA stimulated lymphocyte proliferation in diabetic rats. Thus, control rats when compared to diabetic rats are less sensitive to the deleterious effects of a zinc deficient diet. It is likely that longer periods of zinc deprivation would impair the in vitro cell-mediated immune response in control rats. Previous studies have documented such an effect of zinc deprivation $[8,9]$. It is noteworthy that splenic zinc content in diabetic rats on zinc deficient diet was not significantly different from that in control rats on the same diet. Thus, tissue level of zinc was not a predictor of immune function, which is in agreement with previous studies [18]. Nevertheless, a differential sensitivity of diabetic and control rats to a zinc-deficient diet could be demonstrated. In addition, a high zinc diet normalised the basal and stimulated lymphocyte response in diabetic rats without affecting the control rats. Diabetes - related alterations in mitogenic response of lymphocytes could be mostly prevented by insulin treatment. However, the lymphocyte response to PHA in rats maintained on a low zinc diet could not be normalised with insulin. It is not known whether this is secondary to a toxic side effect of streptozotocin.

The IL-2 production by lymphocytes was not altered in either the diabetic state or dietary zinc deficiency. The previously reported decreased IL-2 production by lymphocytes of Type 1 (insulin-dependent) diabetic patients [3] may well be related to the immune system alteration underlying the pathogenesis of diabetes, rather than a consequence of chronic hyperglycaemia. Alternatively, longer duration of diabetes or feeding a zinc-deficient diet in our studies could have resulted in impaired IL-2 production.

At present, it is not known whether the changes observed in this study are directly related to zinc status or are secondary to biological changes - such as alterations in serum lipoprotein or micronutrient status [10] - induced by zinc deficiency or excess. Overall, zinc status, either directly or indirectly, is an important determinant of cell-mediated immunity and may well be causally related to some aspects of immune system dysfunction in diabetes. Methodological uncertainties make it difficult to correlate tissue zinc content with the degree of immune system impairment. The interpretation of studies on the immune function in diabetes should take into account the zinc status of the animal.

Acknowledgements. Supported by Medical Research Grants from Veterans Administration.

\section{References}

1. Fairchild RS, Kyner JL, Abdou NI (1982) Specific immunoregulation abnormality in insulin dependent diabetes mellitus. J Lab Clin Med 99: 175-185

2. Chandy KG, Charles AM, Kershnar A, Buckingham B, Waldeck N, Gupta S (1984) Autologous mixed lumphocyte reaction in man XV. Cellular and molecular basis of deficient autologous mixed lymphocyte response in insulin-dependent diabetes mellitus. J Clin Immunol 4: 424-428

3. Zier KS, Leo MM, Spielman RS, Baker L (1984) Decreased synthesis of interleukin-2 $\left(\mathrm{IL}_{2}\right)$ in insulin dependent diabetes mellitus. Diabetes 33(6): 552-555

4. Galluzzo A, Giordano C, Rubino G, Bompiani GD (1984) Immunoregulatory $\mathrm{T}$-lymphocyte subset deficiency in newly diagnosed Type 1 (insulin-dependent) diabetes mellitus. Diabetologia 26: 426-430

5. FoVenyi J, Totpal K, Thaisz E, Garam T (1984) Nonspecific cellular immunity in Type 1 and Type 2 diabetes. Exp Clin Endocrinol 83: 203-206

6. Herold KC, Huen A, Gould L, Traisman H, Rubenstein AH (1984) Alterations in lymphocyte subpopulations in Type 1 (insulin dependent) diabetes mellitus: exploration of possible mechanisms and relationships to autoimmune phenomena. Diabetologia 27: 102-105

7. Duchateau J, Delespesse G, Vareake P (1981) Influence of oral zinc supplementation on the lymphocyte response to mitogens of normal subjects. Am J Clin Nutr 34: 88-93 
8. Blazsek I, Mathe G (1984) Zinc and immunity. Biomed Pharma cother 38: 187-193

9. Beisel WR (1982) Single nutrients and immunity. Am J Clin Nutr 35: 417-468

10. Mooradian AD, Morley JE (1987) Micronutrient status in diabetes mellitus. Am J Clin Nutr 45: 877-895

11. Duchateau J, Delepesse G, Vrijens R, Collet H (1981) Beneficial effects of oral zinc supplementation on the immune response of old people. Am J Med 70: 1001-1004

12. Steidemann M, Harrell I (1980) Relation of immunocompetence to selected nutrients in elderly women. Nutr Rep Int 21: 931-940

13. Allen JI, Perri RT, McClain EJ, Kay NE (1983) Alterations in human natural killer cell activity and monocyte cytotoxicity induced by zinc deficiency. J Lab Clin Med 102: 577-589

14. Fernandes G, Nair M, Onoe K, Tanaka T, Floyd R, Good RA (1979) Impairment of cell-mediated immunity functions by dietary zinc deficiency in mice. Proc Natl Acad Sci USA 76: $457-461$

15. Allen JL, Bell E, Boosalis MG, Oken MM, McClain CJ, Levine AS, Morley JE (1985) Association between urinary zinc excretion and lymphocyte dysfunction in patients with lung cancer. Am J Med 79: 209-215

16. Niewoehner CB, Allen JI, Boosalis M, Levine AS, Morley JE (1986) Role of zinc supplementation in Type 2 diabetes mellitus. Am J Med 81: 63-68

17. Lawrence $S$, Charlesworth JA, Pussell BA, Campbell LV, Kotowicz MA (1986) Factors influencing reticulophagocytic function in insulin-treated diabetes. Diabetes 33: 813-818

18. Donaldson DL, Kubo C, Smith CC, Good RA (1986) Effects of genetic diabetes and zinc nutriture on in vivo cell-mediated immunity in the mouse. Am J Clin Nutr 43: 263-271

19. Mahmoud AAF, Rodman HM, Mandel MA, Warren KS (1976)
Induced and spontaneous diabetes mellitus and suppression of cell mediated immunologic responses. J Clin Invest 57: 362-367

20. Fernandes G, Handwerger BS, Yunis EJ, Brown DM (1978) Immune response to the mutant diabetic $\mathrm{C}_{57} \mathrm{BL} / \mathrm{KS}$ $\mathrm{db}+$ mouse. J Clin Invest 61: 243-250

21. Roth MD, Barg M, Michalski R, Arquilla R (1980) Cell mediated immunity in chronically diabetic mice. Diabetes $29: 825-829$

22. Chi DS, Berry DL, Dillon KA, Arbogast BW (1982) Inhibition of in vitro lymphocyte response by streptozotocin - induced diabetic rat serum: a function of very low density lipoproteins. Diabetes 31: 1098-1104

23. Deebaj L, Song MK, Mooradian AD (1988) The effect of dietary zinc content on micronutrient status of control and diabetic rats. Clin Res 36: $96 \mathrm{~A}$

24. James SJ, Swendseid M, Makinodan T (1987) Macrophage mediated depression of $\mathbf{T}$-cell proliferation in zinc deficient mice. $\mathrm{J}$ Nutr 117: 1982-1988

25. Chang MP, Makinodan T, Peterson WJ, Strehler B (1982) Role of T-cells and adherent cells in age-related decline in murine interleukin-2 production. J Immunol 129: 2426-2430

26. Gillis S, Form MM, Ou W, Smith KA (1978) T-cell growth factor: parameters of production and a quantitative microassay for activity. J Immunol 120: 2027-2032

Received: 24 September 1987;

and in revised form: 28 April 1988

Dr. A.D. Mooradian

University of Arizona

1821 E. Elm Street

Tucson, Arizona 85719

USA 